Mazur Karol, Machaj Dominik, Mazur Dominika. Physical activity during pregnancy - literature review. Journal of Education, Health and Sport. 2020;10(1):11-15. eISSN 2391-8306. DOI http://dx.doi.org/10.12775/JEHS.2020.10.01.001 https://apcz.umk.pl/czasopisma/index.php/JEHS/article/view/JEHS.2020.10.01.001 https://zenodo.org/record/3605706

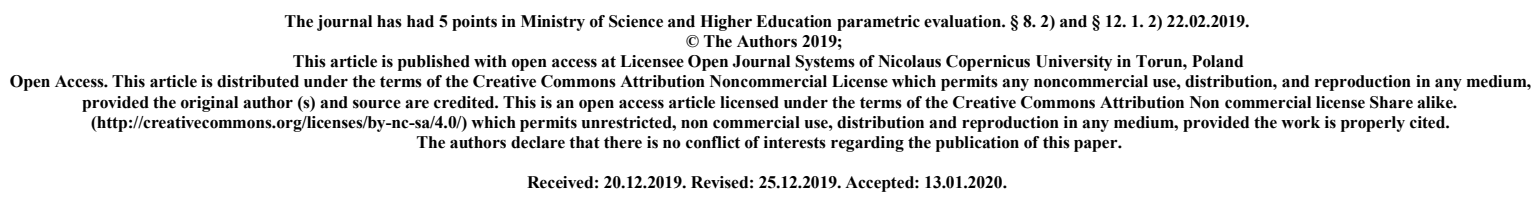

\title{
Physical activity during pregnancy - literature review
}

\section{Mazur Karol, Machaj Dominik, Mazur Dominika}

Karol Mazur, mazurkarol79@gmail.com, Faculty of Medicine, Medical University of Lublin, Chodźki Street 19, 20-093 Lublin, Poland

Dominik Machaj, dominik5a4@tlen.pl, Faculty of Medicine, Medical University of Lublin, Chodźki Street 19, 20-093 Lublin, Poland

Dominika Mazur, dominika.hul20@gmail.com, Medical Faculty, University of Rzeszow, Pigonia Street 6, 35-310 Rzeszow, Poland

\section{Summary:}

Physical activity is one of the basics elements of a healthy lifestyle. Pregnancy is a unique state of physiologic stress which necessitates physical, mental, and social adaptation. Physical activity has significant influence on health of pregnant women. the most important benefits of physical exercising during pregnancy are: preparation for labor effort and reduction of the duration of the labor. The form of the physical activity should be consulted with the midwife or gynecologist, that will choose adequate exercises to the need and possibilities of the pregnant woman. The aim of this study was to evaluate meaning of the physical activity during pregnancy for the women.

The status of women's knowledge about physical exercises in pregnancy is unsatisfactory. The internet is the main source of information about physical activity during pregnancy for pregnant women. There is significant correlation between the awareness of meaning of physical activity during pregnancy and the age, education, attending on childbirth education classes or education of pregnant women. The level of knowledge about meaning of physical activity during pregnancy, time of beginning the exercising, their frequency and the type, contraindications is high in the group of women over 30 years old, married, with high level of education, multiparas and those who attended childbirth education classes. Physical activity during pregnancy is often determined by gestational age, course of pregnancy and exercising before pregnancy. Unfortunately many women stop physical exercising during pregnancy, especially in the first trimester. Main reasons to stop physical exercising are: general feeling of being unwell, medical recommendations, and symptoms related to pregnancy. The most adequate sports for pregnant women are: swimming, yoga, pilates and gymnastics, that are often organized in childbirth education classes Also many pregnant women don't consulate physical exercising during pregnancy with the gynecologist or midwife.

Key words: pregnancy; physical activity; physical exercising, physical activity during pregnancy; 


\section{INTRODUCTION AND PURPOSE}

Physical activity is one of the basics elements of a healthy lifestyle. So more and more people start running, swimming, climbing, exercising in the gym or training yoga. Health benefits of physical exercises depends on the regularity, intensity, duration, level of advancement and proper warm-up [1]. Regular physical activity could prevent from several chronic diseases like cardiovascular disease, diabetes, hypertension, obesity [1,2]. Undertaking physical exercises is also used to treat some psychical diseases like anxiety and depression [2,3]. So it's extremely important to promote a physically active lifestyle and prevent from a being sedentary. We should also remember that physical activity habits developed in early life may persist into adulthood [1,2].

Pregnancy is a unique state of physiologic stress which necessitates physical, mental, and social adaptation [4]. Physical activity has significant influence on health of pregnant women. Unfortunately women reluctantly undertake such activity during pregnancy and they prefer passive rest [5]. Also the status of their knowledge about meaning of the physical exercises during pregnancy is disappointing [6].

Therefore, the most important benefits of physical exercising during pregnancy are: preparation for labor effort and reduction of the duration of the labor. This is possible due to maintaining or increasing cardiopulmonary efficiency, as well as increasing muscle strength and mobility of joints $[5,7,8,9]$.

The form of the physical activity should be consulted with the midwife or gynecologist, that will choose adequate exercises to the need and possibilities of the pregnant woman. This specialist should also check if there are no any contraindications to physical effort $[10,11]$.

The aim of this study was to evaluate meaning of the physical activity during pregnancy for the women. Our study material consisted of publications, which were found in PubMed, Research Gate and Google Scholar databases. In order to find the proper publications, the search has been conducted with the use of a combination of key words like: "pregnancy"", "physical activity", "physical exercising", " physical activity during pregnancy ". The first step to find proper publications from the last 10 years .The second step was to carry out an overview of the found publications. 


\section{DESCRIPTION OF THE STATE OF KNOWLEDGE}

Torbé D et al. study revealed that the status of women's knowledge about physical exercises in pregnancy is unsatisfactory. Especially low level of this knowledge is represented by women younger than 25 years old, primiparas, unmarried and those of only primary level of education. The level of knowledge about meaning of physical activity during pregnancy, time of beginning the exercising, their frequency and the type, contraindications was far more higher in the group of women over 30 years old, married, with high level of education, multiparas and those who attended childbirth education classes than in the group of women mentioned above. For the respondents the internet was the main source of information about physical activity during pregnancy, then in further order books, women's press and the experiences of other women. They also declared that the most proper sports for pregnant women are: home gymnastics, fitness and swimming [6].

Banyś J. A. et al. study showed that $46 \%$ of the respondents, that were pregnant women, reported a decrease of physical activity after becoming pregnant, 10\% - an increase. $44 \%$ of them answered that their physical activity remain unchanged. There was no significant statistical correlation between age of the respondents, place of living, education and change of the level of physical activity before and during pregnancy. $49 \%$ of the respondents said that they didn't talk with the gynecologist or midwife about physical exercises during pregnancy.

Gałązka I. et al. study proved that physical activity during pregnancy is often determined by gestational age and the course of pregnancy. In this study $50 \%$ of pregnant women maintain or increase their physical activity level and $50 \%$ of them decrease their physical activity level. The most popular sport among respondents before and during pregnancy were: swimming, bike cycling, yoga training, pilates, running and gymnastics. $75 \%$ of the respondents, that was physically active before pregnancy, answered that they have stopped exercising in the first trimester, $20,83 \%$ - in the second trimester, $4,17 \%$ - in the third trimester. Among the main reasons to stop physical exercising were: general feeling of being unwell, medical recommendations, and symptoms related to pregnancy. The rest of the respondents weren't exercising before pregnancy as well as during pregnancy [13].

Adequate physical activities for pregnant women are: swimming, aqua aerobic, pilates, gymnastics, yoga, that some of them are often organized by well-educated instructors in childbirth education classes [10,14].Childbirth education classes are also the place that pregnant women with partners can, under the guidance of a specialist, learn how to perform 
systemic, relaxation and breathing exercises, and choose the most recommended activities for themselves. They are also there- apart from a positive attitude and preparation for childbirth mobilized to physical activity $[14,15]$.

However, pregnant women have to stop training: extreme sports (climbing, high diving, mountain biking, bungee jumping), combat sports (boxing, karate, taekwondo, judo, wrestling), winter sports (skiing, snowboarding, ice skating). There is also need to resign from exercises like crunches, that involves abdominal muscles, and from exercises like jumping on the gymnastics trampoline, that increase blood pressure and heart rate $[10,16]$.

According to the guidelines issued by the American Congress of Obstetricians and Gynecologists (ACOG), the absolute contraindications to exercise are: hemodynamic heart diseases, restrictive lung diseases, cervical cerclage, risk of premature birth and premature delivery in the previous pregnancy, bleeding in the second and third trimesters of pregnancy, placenta praevia after the 26th week of pregnancy, premature rapture of membranes, and pregnancy induced hypertension [17].

There aren't any polish recommendations concerning time of beginning, frequency, type and the contraindications for physical activity during pregnancy,

\section{CONCLUSIONS}

1. The status of women's knowledge about physical exercises in pregnancy is unsatisfactory.

2. The internet was the main source of information about physical activity during pregnancy for pregnant women.

3. There is significant correlation between the awareness of meaning of physical activity during pregnancy and the age, education, attending on childbirth education classes or education of pregnant women.

4. The level of knowledge about meaning of physical activity during pregnancy, time of beginning the exercising, their frequency and the type, contraindications is high in the group of women over 30 years old, married, with high level of education, multiparas and those who attended childbirth education classes.

5. Physical activity during pregnancy is often determined by gestational age, course of pregnancy and exercising before pregnancy.

6. Unfortunately many women stop physical exercising during pregnancy, especially in the first trimester. 
7. Main reasons to stop physical exercising are: general feeling of being unwell, medical recommendations, and symptoms related to pregnancy.

8. There are some contraindications to exercise during pregnancy that every physically active woman should know.

9. The most adequate sports for pregnant women are: swimming, yoga, pilates and gymnastics, that are often organized in childbirth education classes.

10. Also many pregnant women don't consulate physical exercising during pregnancy with the gynecologist or midwife.

\section{REFERENCES}

1. Michalski T. „Miejsce aktywności fizycznej wśród czynników wpływających na zdrowie”, Rocznik Naukowy, AWFiS w Gdańsku 2014; 26: 5-10.

2. Woynarowska B. Czynniki warunkujące zdrowie i dbałość o zdrowie. [w:] Edukacja zdrowotna, Woynarowska B (red). PWN, Warszawa 2010: 44-55.

3. Kowalska J., Olszowa D., Markowska D. „Aktywność fizyczna i szkoła rodzenia w czasie ciąży a poziom postrzeganego stresu i objawów depresyjnych u kobiet po porodzie", Psychiatria Polska 2014;48(5): 889-900.

4. Chitryniewicz-Rostek J., Kulis A., Kreska-Korus A. „Wpływ aktywności fizycznej na stan psychofizyczny kobiet w ciąży”, Medical Rehabilitation 2015; 19(1): 9-14.

5. Waleśkiewicz K, Kolesińska-Janowczyk N, Rajewski P et al.: Aktywność fizyczna kobiet w ciąży. [W:] Muszkieta R, Żukow W, Napierała M, Saks E (red.): Stan i rozwój regionalnego sportu i rekreacji. Ośrodek Rekreacji, Sportu i Edukacji w Poznaniu, Bydgoszcz 2010: 192-197.

6. Torbe D, Torbe A, Kregiel K, Ćwiek D, Szych Z. Ocena wiedzy kobiet ciężarnych na temat aktywności fizycznej w ciąży. Nowa Med 2014;4:149-155.

7. Stadnicka G., Łepecka-Klusek C., Pawłowska-Muc A., i in. „Wpływ aktywności fizycznej w okresie ciąży na przebieg porodu", Journal of Education, Health and Sport 2015; 5(9): 505-514.

8. Dudziak D, Guszkowska M. Poczucie kontroli nad bólem porodowym u kobiet aktywnych i nieaktywnych ruchowo w czasie ciąży. Post Rehabil 2013;27(1):23- 29.

9. Kempiak J. Zmiany ustrojowe w przebiegu ciąży. W: Bręborowicz G. (red.). Położnictwo i ginekologia. Warszawa: PZWL; 2013: 41-51.

10. Urtnowska, $\mathrm{K}$ et al. Secure forms of physical activity for pregnant women. Journal of Education, Health and Sport 2016; 6: 291-297.

11. Bień A.M.: Opieka nad kobietą ciężarną, Wyd. Lekarskie PZWL 2009, 186-187.

12. Banyś J. A et al. Physical Activity in Physiological Pregnancy; Piel. Zdr. Publ. 2016, 6, 2, 143147

13. Gałązka I., Kotlarz B., Płóciennik A. i in. „Aktywność fizyczna kobiet w ciąży - czynniki wpływające na podejmowanie lub ograniczenie wysiłku fizycznego", Zdrowie dobrostan 2013; (2): 37-55.

14. Ćwiek D, Szczęsna M, Malinowski W et al.: Analiza aktywności fizycznej podejmowanej przez kobiety w czasie ciąży. Klin Perinatol Ginekol 2012; 5(1): 51-54.Sass A., Mączka M. „Szkoła rodzenia - sposób na realizację aktywności fizycznej kobiet w ciąży?”, Hygeia Public Health 2013; 49(2): 359-364.

15. Stangred A, Cendrowska A, Gawryluk A: Ćwiczenia fizyczne prowadzone w szkole rodzenia, Położ. Nauka Prakt. 2008, 42-51.

16. Cackovic M. A tak przy okazji czy w czasie ciąży można jeździć na nartach. Ginekol Dypl 2007, 9(2): 83-84

17. Artal R., O'Toole M., Guidelines of the American College of Obstetricians and Gynecologists for exercise during pregnancy and the postpartum period. Br. J. Sports Med., 2003, 37, 6-12. 